\title{
Kajian Kelayakan Usaha Pengolahan Tradisional Jambal Roti di UKM Mamah Jambal
}

\author{
[Business Feasibility Study of Jambal Roti Traditional Processing \\ at Mamah Jambal SMEs]
}

\author{
Kamsiah, Ponirah
}

Program Studi Penyuluhan Perikanan, Politeknik Ahli Usaha Perikanan Jl. Cikaret No.2 Bogor Selatan, Kota Bogor

Diterima: 25 September 2021; Disetujui: 31 Desember 2021

\begin{abstract}
Abstrak
Ikan manyung (Arius thalassinus) merupakan bahan baku yang sering digunakan dalam olahan ikan asin Jambal Roti. Istilah Jambal Roti timbul karena daging ikan yang telah digoreng rapuh dan mudah hancur seperti hancurnya roti panggang. Usaha Kecil dan Menengah (UKM) Mamah Jambal merupakan salah satu UKM pengolah hasil perikanan secara tradisional yang memproduksi jambal roti. Tujuan penelitian ini di UKM Mamah Jambal Kabupaten Pangandaran Provinsi Jawa Barat untuk mengetahui kelayakan usaha pengolahan Jambal Roti lkan Manyung (Arius thalassinus) di UKM Mamah Jambal Kabupaten Pangandaran Provinsi Jawa Barat. Metode pengumpulan data yang akan digunakan yaitu wawancara, observasi, penelusuran data sekunder dan dokumentasi. Proses produksi Jambal Roti dilakukan mulai dari penyediaan pasokan input, proses produksi, pasca produksi hingga pemasaran. Metode analisis data yang digunakan adalah analisis data kualitatif yaitu pengolahan data secara mendalam dengan data dari hasil pengamatan, wawancara dan literatur dan analisis data kuantitatif yaitu metode pengolahan data menggunakan rumus korelasi dan skala likert. Hasil dari tujuan penelitian ini yaitu berdasarkan analisis kelayakan usaha pengolahan jambal roti layak untuk dilanjutkan, dilihat berdasarkan $R / C$ ratio sebesar 1,9 . Permasalahan yang dihadapi oleh UKM Mamah Jambal dalam usaha pengolahan ikan jambal roti yaitu ketersediaan bahan baku ikan dari pemasok lokal belum memenuhi kebutuhan, sanitasi dan higiene masih kurang diperhatikan oleh para pengolah, dan daya beli konsumen sempat berkurang pada saat pelaksanaan Pemberlakuan Pembatasan Kegiatan Masyarakat akibat pandemi Covid-19.
\end{abstract}

Kata kunci : analisis usaha; jambal roti; pengolahan tradisional

\section{Abstract}

Catfish (Arius thalassinus) is a raw material that is often used in processed Jambal Roti salted fish. The term Jambal Roti arose because the fish meat that had been fried was brittle and easily crumbled like crushed toast. Mamah Jambal Small and Medium Enterprises (SMEs) is one of the traditional fishery processing SMEs that produces jambal roti. The purpose of this study in Mamah Jambal SMEs, Pangandaran Regency, West Java Province, was to determine the feasibility of processing Jambal Roti lkan Manyung (Arius thalassinus) in Mamah Jambal SMEs, Pangandaran Regency, West Java Province. Data collection methods to be used are interviews, observation, secondary data search and documentation. The Jambal Roti production process is carried out starting from providing input supplies, production processes, post-production to marketing. The data analysis method used is qualitative data analysis, namely data processing in depth with data from observations, interviews and literature and quantitative data analysis, namely data processing methods using correlation formulas and Likert scale. The results of the purpose of this study are based on a feasibility analysis of the business of processing jambal roti which is feasible to continue, seen from the R/C ratio of 1.9. The problems faced by Mamah Jambal SMEs in the Jambal Roti fish processing business are the availability of fish raw materials from local suppliers that have not met the needs, sanitation and hygiene are still not being paid attention to by the 
processors, and the purchasing power of consumers was reduced during the implementation of the Restrictions on Community Activities due to the pandemic Covid-19.

Keywords: business analysis; jambal roti, traditional processing

\section{Penulis Korespondensi}

Ponirah| ponirah181@gmail.com

\section{PENDAHULUAN}

Ikan merupakan salah satu sumber protein hewani yang banyak dikonsumsi masyarakat, mudah didapat dan harganya murah. Namun cepat mengalami proses pembusukan. Pengawetan ikan secara tradisional bertujuan untuk mengurangi kadar air dalam tubuh ikan, salah satunya dengan pembuatan ikan. Penggunaan garam sebagai bahan pengawet yang mempunyai kemampuan menghambat pertumbuhan bakteri dan kegiatan enzim penyebab pembusukan ikan yang terdapat dalam tubuh ikan.

Kajian kelayakan usaha adalah aspek-aspek yang harus dikaji dan diteliti kelayakannya sehingga hasil kajian tersebut digunakan untuk memutuskan apakah sebaiknya usaha tersebut layak dilakukan atau ditunda atau bahkan dibatalkan (Sulastri 2016).

Pengolahan tradisional pada hasil perikanan adalah cara mengolah hasil perikanan yang masih menerapkan teknologi sederhana sebagai usaha untuk mendapatkan nilai tambah pada produk perikanan atau menampung hasil panen yang berlebih (Rakhmawati 2017).
Usaha Kecil dan Menengah (UKM) Mamah Jambal merupakan salah satu UKM pengolah hasil perikanan secara tradisional yang memproduksi jambal roti. UKM Mamah Jambal sudah sangat dikenal oleh konsumennya karena jambal roti hasil produksi UKM Mamah Jambal cukup diminati di pasaran. Oleh karena itu penulis tertarik untuk melakukan penelitian dengan mengambil judul "Kajian Kelayakan Usaha Pengolahan Tradisional Jambal Roti di UKM Mamah Jambal".

\section{BAHAN DAN METODE}

Kegiatan penelitian ini dilaksanakan pada tanggal 1 Juni sampai dengan 30 Juni 2021 di UKM Mamah Jambal Kabupaten Pangandaran Provinsi Jawa Barat. Data yang diambil terdiri atas dua jenis data yaitu data primer dan data sekunder. Data primer diperoleh dari hasil observasi dan wawancara sebanyak dua orang narasumber yaitu pemilik dan pengolah dengan menggunakan kuesioner. Sedangkan data sekunder diperoleh dari hasil studi kepustakaan, analisis catatan, laporan dan dokumentasi. Pengumpulan data dilakukan untuk 
memperoleh informasi yang dibutuhkan dalam rangka mencapai tujuan suatu laporan. Metode pengumpulan data yang akan digunakan yaitu wawancara, observasi, penelusuran data sekunder dan dokumentasi.

Analisis data yang akan dilakukan menggunakan dua metode yaitu analisis data kualitatif dan kuantitatif. Metode analisis data kualitatif adalah pengolahan data secara mendalam dengan data dari hasil pengamatan, wawancara dan literatur. Sedangkan metode analisis data kuantitatif yaitu metode pengolahan data menggunakan rumus korelasi dan skala likert.

\section{HASIL DAN PEMBAHASAN}

Hasil

Kondisi Umum Lokasi Usaha

Kondisi Geografis

Secara astronomis, Kabupaten Pangandaran berada pada $108^{\circ} 30^{\prime}$ sampai dengan $108^{\circ} 40^{\prime}$ Bujur Timur dan $7^{\circ} 40^{\prime} 20^{\prime \prime}$ sampai dengan 7050'20" Lintang Selatan. Dilihat di peta Jawa Barat, Kabupaten Pangandaran terletak paling tenggara. Luas wilayah Kabupaten Pangandaran yaitu $168.509 \mathrm{Ha}$ dengan luas laut 67.340 Ha. Kabupaten Pangandaran memiliki panjang pantai 91 km (BPS 2020).
Profil UKM Mamah Jambal

Usaha Kecil dan Menengah (UKM) Mamah Jambal merupakan usaha pengolahan tradisional. UKM ini berlokasi di jalan Jangilus no. 110, Desa Pangandaran, Kabupaten Pangandaran, Provinsi Jawa Barat, Indonesia. Usaha ini idirikan oleh ibu Mamah dan keluarganya pada tahun 1985. Modal awal usaha ini berasal dari bantuan bahan baku berupa ikan dari Tempat Pelelangan Ikan setempat. Bahan baku ikan yang digunakan yaitu ikan Manyung (Arius thalassinus) yang diolah menjadi jenis jambal roti super dan biasa.

Sistem Usaha Pengolahan Jambal Roti Pasokan Input

Modal

Modal awal usaha UKM Mamah Jambal berasal dari bantuan bahan baku berupa ikan dari Tempat Pelelangan Ikan setempat. Modal saat ini merupakan modal pribadi dan akses permodalan KUR dari bank setempat. Modal yang dimiliki digunakan untuk memperoleh bahan baku dan sarana prasarana. Produk yang dihasilkan akan dipasarkan langsung ke konsumen maupun melalui tangan pemasar. Hasil dari pemasaran akan digunakan kembali sebagai modal, tabungan dan pengembangan usaha. 


\section{Bahan Baku}

Ikan

Ikan merupakan pasokan input utama dan terpenting dalam usaha pengolahan ikan asin jambal roti (Burhanuddin et al. 1984). Ikan yang digunakan dalam pembuatan jambal roti ini berjenis ikan Manyung (Arius thalassinus). Kebanyakan ikan ini hidup di dua habitat, yaitu mula-mula di air tawar lalu bermuara ke perairan estuari untuk memijah. Penyebaran ikan Manyung di Indonesia meliputi perairan laut barat Sumatera Selatan, Jawa, Selat Malaka, Timur Sumatera, Utara Jawa, Bali-Nusa Tenggara Timur, Selatan dan Barat Kalimantan, Selatan Sulawesi, Utara Sulawesi, Maluku dan Irian (Gloerfelt dan Kailola 1980).

Bahan baku ikan yang digunakan di UKM Mamah Jambal berasal dari hasil tangkap lokal dan luar daerah seperti Cilacap. Selama pelaksanaan penelitian, persentase asal bahan baku ikan yang digunakan yaitu bahan baku ikan dari TPI Pangandaran sebesar $36 \%$ dan hasil tangkap dari TPI Cilacap sebesar 64\%. Hal ini dikarenakan produksi tangkap lokal sedang menurun sehingga menggunakan bahan baku ikan dari luar daerah.

Selama pelaksanaan penelitian, persentase tingkat kesegaran ikan yang digunakan dalam 11 kali penerimaan bahan baku yaitu 64\% menggunakan ikan segar dan 36\% menggunakan ikan kurang segar. Kesegaran ikan mempengaruhi cara pengolahan yang dilakukan, ikan segar diolah menjadi jambal roti dengan kualitas baik atau super dan ikan kurang segar diolah menjadi jambal roti dengan kualitas kedua.

\section{Garam}

Jenis garam yang digunakan adalah garam kristal atau garam krosok. Harga garam yaitu Rp. 60.000/karung dengan berat $25 \mathrm{Kg}$. Bahan baku garam ini biasanya dikirim dari penyuplai asal Pati yang mengantarkan ke UKM Mamah Jambal.

\section{Tenaga Kerja}

Tenaga kerja merupakan anggota keluarga dengan jumlah 7 orang. Pengetahuan dan keterampilan dalam mengolah jambal roti diperoleh dari pengalaman belajar sendiri, dengan mengamati dan mengikuti proses pengolahan jambal roti orang lain.

\section{Proses Produksi}

Persiapan alat dan bahan

Alat yang digunakan antara lain jolang, ember, pisau, talenan, jengkok, sarung tangan, keranjang, air, garam, dan lain-lain. Ketika bahan baku ikan sudah tiba maka diletakkan di tempat produksi. 


\section{Penimbangan I}

Kegiatan penimbangan I ditujukan untuk mengetahui berat awal ikan yang akan diproduksi. Dalam kegiatan ini sekaligus penghitungan banyak ikan atau jumlah ekor. Kegiatan penimbangan ini biasanya ikan dimasukkan ke dalam keranjang yang sudah disiapkan di atas penimbangan.

\section{Penyiangan ikan}

Sebelum ikan digarami, dilakukan penyiangan. Pada saat tersebut juga dilakukan pengecekan ulang tingkat kesegaran ikan karena menentukan jenis produksi yang akan dilakukan. Tingkat kesegaran ikan tergantung perlakuan dan lama penyimpanan (Lestari, Yuwana, dan Efendi 2015). Selain karena keadaan bahan baku ikan saat diterima dari penyuplai, karakteristik pengolah juga mempengaruhi mutu ikan kering yang dihasilkan (Fajar, Salman, dan Tibrani 2014). Jika kesegaran bahan baku ikan sangat bagus maka akan diolah menjadi jambal roti super, sedangkan bahan baku dengan kesegaran nomor 2 makan diolah menjadi jambal roti biasa.

Bahan baku ikan dengan kesegaran bagus, akan dipotong bagian kepala karena tidak digunakan, kemudian buang bagian isi perut. Sedangkan bahan baku ikan dengan kesegaran nomor 2, dilakukan pemotongan ujung mulut ikan atau bagian yang terdapat kumis. Setelah itu dilakukan pembelahan ikan dari ujung ekor serta bagian dinding, buang tulang dan perut dibersihkan dari kotoran atau isi perut ikan.

\section{Pencucian I}

Ikan dimasukkan ke dalam jolang atau blong kemudian disiram dengan air mengalir untuk menghilangkan kotoran yang menempel. Kemudian ikan dapat disimpan di keranjang sebelum dilakukan proses selanjutnya.

\section{Penggaraman}

Garam berperan sebagai elektrolit kuat yang dapat merusak ikatan molekul air dalam protein denaturasi. Denaturasi pada protein (transformasi struktur protein yang berlipat menjadi terbuka), terutama enzim, menyebabkan proses autolisis bahan terhambat (Zaitsev et al. 1969). Penggunaan garam dibutuhkan untuk mengurangi kemungkinan pertumbuhan bakteri patogen (Karyantina et al. 2021).

Proses penggaraman bahan baku ikan yang akan diproduksi menjadi jambal roti super, dilakukan dengan cara memasukkan garam ke dalam rongga perut ikan dengan kepadatan sedang. Setelah itu ikan dapat ditata di dalam blong penggaraman. Bagian dasar blong terlebih dahulu diberikan lapisan garam, kemudian susun ikan di atasnya dengan 
rapi. Setiap lapisan ikan ditaburi garam sampai tidak terlihat lapisan ikan. Proses penggaraman berlangsung selama 4-6 hari. Proses penggaraman ini akan menghasilkan daging ikan yang bertekstur lembek dan lembut. Larutan garam yang lebih pekat di luar tubuh ikan menyebabkan air di dalam tubuh ikan keluar, semakin lama cairan sisa dalam tubuh ikan semakin kental dan proteinnya akan menggumpal serta sel daging akan mengerut (Moeljanto 1982).

Untuk bahan baku ikan yang akan diproduksi menjadi jambal roti biasa, proses penggaraman dapat dilakukan di blong atau bak penggaraman. Setiap lapisan ikan ditaburi garam sampai tidak terlihat lapisan ikan. Dan bagian lapisan paling atas diberikan lapisan garam lebih tebal seperti lapisan dasar. Proses penggaraman berlangsung selama 1-2 hari. Proses penggaraman ini akan menghasilkan daging ikan yang bertekstur padat.

Konsentrasi garam dan lama fermentasi akan mempengaruhi penampakan, aroma, tekstur dan rasa jambal roti (Rochima 2005). Menurut Maulid dan Abrian (2020) kadar garam Jambal Roti yang berasal dari Pangandaran berkisar 4,76-13,17\%, menurut SNI ikan asin 8273:2016, maka kadar garam berada pada kisaran nilai SNI yaitu $12-20 \%$.

\section{Pembelahan}

Kegiatan pembelahan ini dilakukan untuk bahan baku yang dilakukan proses penggaraman dalam bentuk utuh tanpa kepala. Setelah proses penggaraman selesai, maka ikan dikeluarkan dari media penggaraman. Garam pada isi perut ikan dikeluarkan, ikan dicuci untuk menghilangkan garam yang masih menempel pada ikan. Belah ikan menggunakan pisau dengan hati-hati karena ikan bertekstur lembek. Dalam proses pembelahan ikan dilakukan pembuangan tulang ikan dari pangkal ekor sampai bagian atas. Setelahnya ikan disimpan ke dalam jolang dengan hati-hati.

\section{Penyikatan}

Proses penyikatan dilakukan dengan hati-hati agar tidak merusak bagian daging. Terlebih dahulu menyiapkan air di dalam jolang. Ikan tidak dimasukkan ke dalam air, sikat satu per satu dengan pelan untuk menghilangkan kotoran yang tersisa. Setelah penyikatan selesai, ikan dapat langsung dilakukan proses penjemuran.

\section{Pencucian II}

Untuk bahan jambal roti biasa, setelah dilakukan penyikatan selanjutnya dilakukan pencucian sebelum tahap penjemuran. Ikan di tata di dalam jolang agar dapat terendam dalam air. Pada tahap ini juga dapat dilakukan peren- 
daman untuk mengurangi kadar asin ikan. Biasanya dilakukan selama 10-30 menit. Pada proses pencucian yang ini tidak membutuhkan waktu yang lama, istilah yang digunakan yaitu "gombyang" atau ikan digoyang sebentar di dalam air kemudian diangkat.

\section{Pengeringan}

Pengeringan merupakan suatu metode untuk mengeluarkan atau menghilangkan sebagian air dari suatu bahan dengan cara menguapkan air tersebut dengan menggunakan energi panas.

Pengeringan alami adalah proses pengeringan yang dilakukan dengan menggunakan media angin dan sinar matahari. Ikan-ikan dijemur di atas rakrak ke arah datangnya angin dan ditempatkan di tempat terbuka terkena sinar matahari dan hembusan angin secara langsung (Budiman 2004).

Proses pengeringan di UKM Mamah Jambal dilakukan dengan cara ikan ditata di atas papan penjemuran dengan rapi. Untuk bahan jambal roti super, setelah ditata dilakukan pengolesan air bawang dengan tujuan untuk merapikan lapisan daging paling luar, menghasilkan aroma yang wangi serta untuk menghilangkan belatung (Burhanuddin 1987). Proses penjemuran rata-rata berlangsung selama satu hari, jika kondisi cuaca mendung atau hujan maka membutuhkan waktu yang lebih lama.

\section{Penimbangan II}

Setelah proses penjemuran selesai, ikan diangkut menggunakan irig kemudian dilakukan penimbangan kedua. Penimbangan ini untuk mengetahui berat akhir atau penyusutan. Penimbangan ini dilakukan dengan timbangan digital.

\section{Penirisan}

Proses penirisan dilakukan jika ikan masih dalam kondisi hangat. Proses penirisan ini biasanya dilakukan di lantai gudang bagian dalam dan luar dengan dialasi tikar mending. Proses penirisan dilakukan selama 30-60 menit.

\section{Pasca Produksi}

Menurut Junianto (2003) ada beberapa penanganan yang dapat dilakukan setelah dilakukannya proses produksi yaitu dengan memberikan kemasan dan melakukan penyimpanan. Kegiatan pasca produksi merupakan proses atau kegiatan penanganan ikan setelah diproduksi. Untuk jambal roti super, jika akan dijual di kios maka dilakukan penyimpanan di dalam freezer. Tata ikan dengan posisi daging terbuka, setiap lapisan ikan dilapisi dengan kertas pembungkus agar tidak saling menempel. Perlu pengontrolan belatung jika ikan disimpan dalam jangka yang lama. Jika muncul belatung maka dilakukan penyi- 
katan tanpa air. Penyimpanan di dalam freezer dapat berlangsung selama \pm 6 bulan, sedangkan dalam suhu normal dapat disimpan selama 3-4 hari. Untuk jambal roti super yang dibeli oleh distributor dikemas menggunakan kardus dan dilapisi kertas pembungkus dalam setiap lapisnya, biasanya diangkut menggunakan becak atau kendaraan bermotor.

Untuk jambal roti biasa, jika akan dijual di kios maka dilakukan proses pengemasan menggunakan plastik PP ukuran $2 \mathrm{~kg}$, dibungkus kertas pembungkus, bagian ekor diikat menggunakan tali rafia lalu disimpan di kios atau digantung. Untuk jambal roti biasa yang dibeli oleh distributor, dikemas menggunakan karung atau kardus, dapat ditali atau dilem agar bagian kardus tidak terbuka, selanjutnya dapat diangkut menggunakan becak atau kendaraan bermotor. Selain itu, dilakukan pula kebersihan di lingkungan tempat produksi maupun kios.

\section{Pemasaran}

Pangandaran memiliki potensi pariwisata, sektor pariwisata yang dimiliki dapat digunakan sebagai leading sector khususnya bagi daerah berkembang seperti kabupaten Pangandaran. Di mana banyaknya aspek kuliner khas kabupaten Pangandaran yang dapat dijadikan nilai tambah ekonomi (Mutaqin dan Natari 2021). Menurut Assauri (2017) terdapat empat unsur dasar pada pemasaran yang terdiri 4P yaitu product (produk), price (harga), place (tempat).

\section{Produk}

Jambal Roti adalah salah satu pengolahan hasil perikanan tradisional yang cukup banyak diminati oleh masyarakat umum atau wisatawan di Kabupaten Pangandaran. Jambal Roti dijadikan oleh-oleh ketika wisatawan selesai berlibur ataupun masyarakat umum yang ingin menikmatinya. Berdasarkan hasil pengamatan dan wawancara, para pengolah menjaga kebersihan lingkungan dan peralatan dengan cukup baik. Sedangkan kuantitas, melihat dari ketersediaan produk yang disiapkan untuk melakukan pemasaran. Berdasarkan pengamatan dan wawancara, jumlah jambal roti yang diproduksi sudah memenuhi kebutuhan pasar. Hal ini dinilai dari produk yang habis terjual. Menurut Firiyanti (2019), produk jambal roti di Kabupaten Pangandaran secara organoleptik telah memenuhi syarat standar mutu menurut SNI.

\section{Harga}

Harga jual ditentukan berdasarkan harga pokok pembelian bahan baku. Ikan jambal roti dijual dengan harga per $\mathrm{kg}$. Harga jual ikan jambal roti bervariasi berdasarkan jenis produk dan ukuran ikan. Harga jual jambal roti di UKM 
Mamah Jambal dapat dilihat pada Promosi

Tabel 1.

Para pengolah melakukan promosi produk secara manual dan sederhana.

Penyaluran

Produk Jambal Roti langsung dipaPromosi dilakukan secara langsung ke konsumen, seperti dengan menawarkan sarkan di kios yang bersebelahan deproduk pada saat penjualan. Promosi ngan tempat produksi. Selain itu juga juga dilakukan di akun media sosial oleh dipasarkan melalui tangan distributortenaga kerja UKM Mamah Jambal. distributor langganan.

Kemudian sering dilakukan pengambilan foto dan video oleh konsumen yang

Tabel 1. Harga Jual

\begin{tabular}{cccc}
\hline \multirow{2}{*}{ No. } & \multirow{2}{*}{ Produk } & \multicolumn{2}{c}{ Harga Jual (Per Kg) } \\
\cline { 3 - 4 } & & Harga Umum (Rp.) & Harga Distributor (Rp.) \\
\hline 1 & Jambal Roti Super & 120.000 & 110.000 \\
2 & Jambal Roti Biasa & 80.000 & 70.000 \\
\hline
\end{tabular}

Tabel 2. Analisis Usaha

\begin{tabular}{clcrr}
\hline No. & \multicolumn{1}{c}{ Keterangan } & Satuan & \multicolumn{1}{c}{ A } & \multicolumn{1}{c}{ B } \\
\hline 1. & Biaya Investasi & Rp. & 403.499 .000 & 403.499 .000 \\
2. & Biaya Penyusutan & Rp. & 4.295 .392 & 4.295 .392 \\
3. & Biaya Variabel/Hari & Rp. & 2.164 .150 & 1.310 .817 \\
4. & Biaya Variabel/Bulan & Rp. & 64.924 .500 & 39.324 .500 \\
5. & Biaya Total Produksi/Bulan & Rp. & 74.372 .696 & 47.722 .696 \\
6. & Pendapatan/Hari & Rp. & 4.626 .666 & 1.946 .000 \\
7. & Pendapatan/Bulan & Rp. & 138.800 .000 & 53.380 .000 \\
8. & Keuntungan/Hari & Rp. & 2.147 .576 & 355.243 \\
9. & Keuntungan/Bulan & Rp. & 64.427 .304 & 10.657 .304 \\
10. & Keuntungan/Tahun & Rp. & 773.127 .648 & 127.887 .648 \\
11. & R/C & - & 1.9 & 1.2 \\
12. & Payback Period(PP) & Tahun & 6.3 & 37.9 \\
13. & ROI & $\%$ & $86,6 \%$ & $22.3 \%$ \\
14. & BEP Rupiah & Rp. & 8.156 .030 & 13.099 .078 \\
15. & BEP Unit & Kg & 39.030 & 61.394 \\
16 & HPP & Rp. & 63.566 & 58.198 \\
\hline
\end{tabular}


diunggah di media sosialnya sehingga membantu mempromosikan produk jambal roti hasil produksi UKM Mamah Jambal.

\section{Lembaga/Layanan Pendukung}

Proses produksi para pengolah sudah didukung dengan sarana transportasi, komunikasi, sumber air dan listrik yang baik. UKM Mamah Jambal didukung oleh Dinas Kelautan Perikanan dan Ketahanan Pangan Kabupaten Pangandaran. Sedangkan dari instansi pemerintah Desa Pangandaran sendiri berusaha mendukung dan menjembatani jika terdapat program-program dari Dinas Perikanan atau dinas terkait lainnya.

\section{Pembahasan}

\section{Analisis Usaha}

Analisis usaha Jambal Roti di UKM Mamah Jambal dapat dilihat pada Tabel 2. ROI merupakan parameter untuk mengetahui tingkat pengembalian investasi dari revenue (penerimaan) yang diterima pemilik (Fauzi 2019) . Nilai ROI gabungan yaitu $18,6 \%$, sedangkan ROI per produk masing-masing $16 \%$ dan $2.6 \%$, yang artinya secara penghitungan ROI gabungan UKM Mamah Jambal mendapatkan keuntungan Rp. 18,8 dalam setiap Rp. 100 biaya yang diinvestasikan, sedangkan untuk ROI Jambal Roti Super dan Jambal Roti Biasa masing-masing mendapatkan keun- tungan Rp. 16 dan Rp. 2.6 dalam setiap Rp. 100 biaya yang diinvestasikan (Asnidar 2017).

Produk jambal roti super memiliki nilai $\mathrm{R} / \mathrm{C}$ ratio yaitu 1.9 dan $R / C$ ratio jambal roti biasa yaitu 1.2, artinya usaha yang dilakukan layak untuk dilakukan. Hal ini sesuai yang dinyatakan oleh (Asnidar 2017) bahwa jika hasil perhitungan yang diperoleh $>1$, artinya usaha layak untuk diusahakan, jika $<1$, artinya usaha tidak layak untuk diusahakan dan jika $=1$, artinya usaha ada pada titik impas. Sehingga semakin tinggi nilai $R / C$ ratio semakin layak usaha tersebut dijalankan.

Seberapa cepat suatu investasi dapat kembali dapat diukur dengan menggunakan metode analisis usaha payback period (Zain, Triarso, dan Hapsari 2016). Kriteria penilaian yaitu jika nilai PP kurang dari 3 tahun masuk dalam kategori cepat, nilai PP 3-5 tahun merupakan kategori sedang dan jika nilai lebih dari 5 tahun masuk dalam kategori lambat (Damayanti 2016).

\section{Permasalahan}

Permasalahan yang dihadapi oleh UKM Mamah Jambal dalam usaha pengolahan ikan jambal roti adalah sebagai berikut :

1. Ketersediaan bahan baku ikan dari pemasok lokal belum memenuhi kebutuhan sehingga mendapatkan 
bahan baku dari luar kota yang terkadang bahan baku yang didapatkan dalam keadaan beku atau kesegaran tidak bagus.

2. Sanitasi dan higiene masih kurang diperhatikan oleh para pengolah sehingga mengurangi kualitas produk yang dihasilkan.

3. Daya beli konsumen sempat berkurang ketika pandemi Covid-19 yang menyebabkan produksi harus dikurangi sehingga pendapatan menurun.

\section{SIMPULAN DAN SARAN}

\section{Simpulan}

Kesimpulan dari penelitian ini adalah sebagai berikut :

1. Usaha jambal roti layak untuk dilanjutkan, dilihat berdasarkan $R / C$ ratio.

2. Usaha jambal roti dilakukan mulai dari penyediaan pasokan input, proses produksi, pasca produksi hingga pemasaran. Ketersediaan bahan baku, modal dan tenaga kerja serta penyediaan sarana dan prasarana telah terpenuhi sehingga kegiatan terlaksana dengan baik.

3. Proses produksi pengolahan jambal roti dilakukan melalui proses yang cukup baik sehingga menghasilkan produk ikan jambal roti yang layak dikonsumsi.

\section{Saran}

Setelah melaksanakan Penelitian ini di UKM Mamah Jambal, saran yang dapat diberikan adalah sebagai berikut :

1) Perlu dilakukannya penerapan sanitasi dan higiene yang lebih intens dalam pengolahan jambal roti agar kualitas produk lebih baik.

2) Perlu adanya penambahan pemasok bahan baku ikan untuk menekan jumlah produk agar tidak habis terjual.

3) Meningkatkan peran serta dan kerja sama antara UKM pengolahan perikanan dengan pemerintah desa dan dinas perikanan setempat.

\section{PERSANTUNAN}

Ucapan terima kasih penulis sampaikan kepada Seluruh Sivitas Akademik Politeknik Ahli Usaha Perikanan Program Studi Penyuluhan Perikanan, Dinas Kelautan Perikanan dan Ketahanan Pangan Kabupaten Pangandaran dan UKM Mamah Jambal yang telah memberikan dukungan, bimbingan, dan semangat dalam penelitian dan penulisan jurnal ini.

\section{DAFTAR PUSTAKA}

Asnidar. 2017. “Teknik Pengolahan Tradisional Dan Manajemen Pemasaran Jambal Roti Ikan 
Manyung (Arius Thalassinus) Di UKM Mamah Jambal Kabupaten Pangandaran Provinsi Jawa Barat." Jurnal Sains Pertanian 1(2):39-47. Assauri, Sofjan. 2017. Manajemen Pemasaran: dasar konsep. dan strategi. 15 ed. Jakarta (ID): PT Rajawali Press.

BPS. 2020. Kabupaten Pangandaran Dalam Angka 2020. Ciamis (ID): BPS Kabupaten Ciamis.

Budiman, Muhammad Syarif. 2004. Teknik Penggaraman dan Pengeringan. Jakarta (ID): Departemen Pendidikan Nasional.

Burhanuddin. 1987. Sumberdaya Ikan Manyung di Indonesia. Jakarta (ID): Puslitbang Oseanologi.

Burhanuddin, Sularto Martosewojo, Asikin Djamali, dan R. Moeljanto. 1984. Perikanan Demersal di Indonesia. Jakarta (ID): Lembaga Oseanologi Nasional LIPI.

Damayanti, Herna Octivia. 2016. "Kelayakan Usaha Industri Ikan Pindang Skala Rumah Tangga di Kabupaten Pati." Jurnal Litbang: Media Informasi Penelitian, Pengembangan dan IPTEK 12(1):22-31. doi:

10.33658/jl.v12i1.49.

Fajar, Salman, dan Tibrani. 2014. "Analisis Agroindustri dan Pemasaran Ikan Asin (Studi Kasus di Desa Nelayan Kecamatan Bangko Kabupaten Rokan Hilir)." Jurnal Dinamika Pertanian 29(3).

Fauzi. 2019. Pengantar Manajemen. 1 ed. Jakarta (ID): Andi Publisher.

Firiyanti, Linda. 2019. "Sistem Manajemen Mutu Pembuatan Ikan Asin Jambal Roti Sampai Dengan Pemasaran di Kabupaten Pangandaran ( Studi Kasus BUMD dan Nelayan di Kabupaten Pangandaran)." AGRISIA - Jurnal IImu-IImu Pertanian 12(1).

Gloerfelt, Thomas, dan Patricia Kailola. 1980. Trawled fishes of Southern Indonesia and Northwestern Australia. The Directorate General of Fisheries.

Junianto. 2003. Teknik Penangan Ikan. Jakarta (ID): Penebar Swadaya.

Karyantina, Merkuria, Sri Anggrahini, Tyas Utami, dan Endang Sutriswati Rahayu. 2021. "Karakteristik Jambal Roti Ikan Manyung (Arius thalassinus) dengan Suplementasi Bakteri Asam Laktat Indigenous." AGROINTEK 15(2):676-84. doi: 10.21107/agrointek.v15i2.9035.

Lestari, Novia, Yuwana, dan Zulman Efendi. 2015. "Identifikasi Tingkat Kesegaran dan Kerusakan Fisik Ikan di Pasar Minggu Kota Bengkulu." Jurnal Agroindustri $5(1): 44-56$. 
Maulid, Deden Yusman, dan Satriya Abrian. 2020. "Kandungan Garam dan Komposisi Proksimat Ikan Asin Jambal Roti dari Pangandaran." MARLIN 1(1):1. doi: 10.15578/marlin.V1.I1.2020.1-6.

Moeljanto. 1982. Penggaraman dan Pengeringan Ikan. 2 ed. Jakarta (ID): PT Penebar Swadaya.

Mutaqin, Bambang, dan Sari Usih Natari. 2021. "Analisis Potensi Ekspor Produk Ikan Asin Jambal Roti di Kabupaten Pangandaran." SULUH: Jurnal Abdimas 2(2):97-104. doi: 10.35814/suluh.v2i2.1740.

Rakhmawati, Lilik. 2017. "Modul Pengolahan Hasil Perikanan Tradisional." Diambil 20 September 2021

(https://edokumen.com/document/351f_mod ul-pengolahan-hasil-perikanantradisional-kelompok.html).
Rochima, Emma. 2005. "Pengaruh Fermentasi Garam terhadap Karakteristik Jambal Roti." Buletin Teknologi Hasil Perikanan 8(2). doi: 10.17844/jphpi.v8i2.1017.

Sulastri, Lilis. 2016. Studi Kelayakan Bisnis untuk Wirausaha. Bandung (ID): LGM - LaGood's Publishing.

Zain, Habieb Noor, Imam Triarso, dan Trisnani Dwi Hapsari. 2016. "Analisis Kelayakan Finansial Usaha Perikanan Tangkap Jaring Insang Permukaan (Surface Gill Net) di Pangkalan Pendaratan Ikan (Ppi) Banyutowo Kabupaten Pati." Journal of Fisheries Resources Utilization Management and Technology 5(1):162-69.

Zaitsev, V., I. Kizevetter, L. Lagunov, T. Makarova, L. Minder, dan V. Podsevalov. 1969. Fish Curing and Processing. Mosco: MIR Publishers. 